\title{
Pengaruh Pupuk Organik Cair (POC) Terhadap Perkecambahan Cendana (Santalum album L.) Secara In Vitro di Nusa Tenggara Timur
}

\section{Effect of Liquid Organic Fertilizer (LOF) on In Vitro Sandalwood (Santalum album L.) Germination in East Nusa Tenggara}

\author{
Hartini Realista Lydia Solle ${ }^{1 *}$, Merpiseldin Nitsae ${ }^{1}$, Mellissa Erlyn Stephanie Ledo ${ }^{1}$ \\ ${ }^{1}$ Pendidikan Biologi, Fakultas Keguruan dan Ilmu Pendidikan, Universitas Kristen Artha Wacana, Kupang \\ Email: hartinisolle21@gmail.com \\ *Penulis korespondensi
}

\begin{abstract}
Sandalwood (Santalum album L.) is a plant which produces wood in East Nusa Tenggara (NTT) and it has a high economic value. This plant is an endemic species. which has superior oil content and good woods terrace production. Sandalwood oil produces popularfragrance. Sandalwood is used as a basic ingredient in perfume, soap, carvings and incense. The presence of sandalwood is currently decreasing, which is caused by locals' exploitation. Efforts to restore the sandalwood plantations have been carried out a lot, such as the conservation efforts by planting sandalwood started from its nurseries and the saplings maintenance that is from natural spreading.However it does not bring satisfactory results. Therefore, plant propagation through tissue culture is one of the best ways of conservation to solve the problem. The purpose of this study was to determine the effect of giving LOF to sandalwood seed growth. This research was carried out by adding Liquid Organic Fertilizer (LOF) to the MS medium. The results showed that the addition of nasa to the MS medium had a good effect on sandalwood germination (Santalum album L.) with a concentration of 2 mLwhich was the optimal concentration. Germination response was shown at 14 days after planting on MS medium.
\end{abstract}

Keywords : Sandalwood, Liquid Organic Fertilizer, nasa, Germination, Murashige and Skoog

\begin{abstract}
Abstrak
Cendana (Santalum album L.) merupakan tanaman hutan penghasil kayu di provinsi Nusa Tenggara Timur (NTT) dan mempunyai nilai ekonomi tinggi. Tanaman ini merupakan spesies endemikyang mempunyai keunggulan kadar minyak dan produksi kayu teras yang baik. Minyak cendana yang dihasilkan memiliki aroma yang harum sehingga banyak digemari. Kayu cendana digunakan sebagai bahan dasar parfum, sabun, ukiran dan kemenyan. Keberadaan cendana di NTT saat ini jumlahnya semakin menurun karena eksploitasi oleh penduduk setempat. Upaya pemulihan tanaman cendana NTT telah banyak dilakukan, seperti usaha pengembangan dengan penanaman cendana dari pembibitan maupun pemeliharaan anakan yang berasal dari penyebaran secara alami akan tetapi usaha tersebut tidak cukup berhasil. Untuk memecahkan masalah tersebut, perbanyakan tanaman melalui kultur jaringan menjadi salah satu cara terbaik dalam upaya konservasi. Tujuan penelitian ini untuk mengetahui pengaruh pemberian POC terhadap pertumbuhan biji cendana secara invitro. Penelitian ini dilakukan dengan menambahkan Pupuk Organik Cair (POC) pada medium Murashige and Skoog (MS). Hasil penelitian menunjukkan bahwa penambahan konsentrasi $2 \mathrm{~mL}$ POC nasa pada medium MS berdampak baik terhadap perkecambahan Cendana (Santalum album L.) dengan konsentrasi $2 \mathrm{~mL}$ yang merupakan konsentrasi optimal. Respon perkecambahan ditunjukan pada 14 hari setelah ditanam pada medium MS.
\end{abstract}

Kata kunci : Cendana, pupuk organik cair, nasa, perkecambahan, Murashige and Skoog

Diterima: 20 Agustus 2019, disetujui: 2 September 2019

\section{Pendahuluan}

Cendana (Santalum album Linn.) merupakan tanaman hutan penghasil kayu di provinsi Nusa Tenggara Timur (NTT) karena mempunyai nilai ekonomi tinggi dan merupakan jenis spesies endemik. Kayu cendana digunakan sebagai bahan dasar 
parfum, sabun, ukiran dan kemenyan. Minyak cendana yang dihasilkan memiliki aroma yang harum sehingga banyak digemari. Secara alami, daerah persebaran cendana terpusat di kawasan lahan kering NTT yaitu pulau Timor, Sumba, Flores. Keberadaan cendana di NTT sekarang ini jumlahnya semakin menurun, hal ini ditunjukkan dengan semakin berkurangnya jumlah pohon cendana. Berdasarkan survei yang dilakukan oleh Dinas Kehutanan Provinsi NTT tahun 1998, jumlah induk dan anakan cendana di Pulau Timor adalah sekitar 250.940 pohon (Anonymous.,2011). Menurut catatan IUCN Red List, cendana termasuk ke dalam golongan tanaman hampir punah (vurnerable).

Perbanyakan tanaman keras telah dilakukan, seperti perbanyakan tanaman cendana (Santalum album L.) secara in vitro yang menunjukan bahwa penggunaan medium $1 / 2$ MS dengan konsentrasi $2 \mathrm{mg} / \mathrm{L}$ NAA dapat menginduksi perkecambahan cendana (Solle $e t$ $a l$, 2016). Aplikasi BAP 1 ppm dan kinetin 1 ppm dalam medium MS terhadap pertumbuhan eksplan ujung apikal tanaman jati menjadi kalus dan tunas (Lina $d k k$., 2013). Penggunaan teknik pematahan dormansi untuk mempercepat perkecambahan dan pertumbuhan cendana juga telah dilakukan dan memberikan hasil terbaik pada metode mekanik (pengamplasan) sebanyak 30\% biji cendana dapat berkecambah dan bertumbuh dengan baik sedangkan untuk metode kimia menggunakan $\mathrm{KNO}_{3}$ memberikan persen perkecambahan sebanyak 27\% (Ndolu, 2018).

Kultur in vitro merupakan suatu metode yang digunakan untuk mengisolasi bagian tanaman seperti sel, jaringan atau organ serta menumbuhkan secara aseptik pada medium budidaya sehingga bagian tanaman tersebut dapat memperbanyak diri dan beregenerasi menjadi tanaman lengkap kembali (Indrianto, 2003). Tanaman pada umumnya memiliki sifat Totipotensi dan autonom. Tumbuh dan berkembang secara independen, jika diisolasi dari jaringan induknya sedangkan untuk totipotensi sebagai kemampuan dari sel tumbuhan (baik sel somatik maupun gametik) untuk beregenerasi menjadi tanaman lengkap kembali (Indrianto, 2003). Media tanam harus berisi semua komponen makronutrien dan mikronutiren yang diperlukan untuk menjamin pertumbuhan eksplan. Bahan-bahan yang dibuat berisi campuran garam mineral sumber unsur makro dan unsur mikro, gula, protein, vitamin, hormon tumbuh. Medium Murashige dan Skoog (MS) (1962), merupakan medium yang paling popular digunakan hampir semua macam tanaman, terutama herbaceous. Medium ini paling banyak digunakan untuk kultur kalus dan tunas, mempunyai konsentrasi garam-garam mineral yang tinggi dan senyawa $\mathrm{N}$ dalam bentuk ammonium dan nitrat serta kalium. Medium MS lebih banyak dipakai karena unsur-unsur dan persenyawaannya lebih lengkap.

\section{Metode Penelitian}

Penelitian ini dilakukan di
Laboratorium Bioteknologi Politeknik Pertanian Kupang, selama 3 bulan dari bulan April - Juli 2019. Bahan yang digunakan antara lain: biji Cendana (Santalum album L.) yang diperoleh dari kabupaten Sumba, Nusa Tenggara Timur, Medium Murashige and Skoog (MS) yang mengandung unsur hara makronutrien dan mikronutrien, gula, air kelapa $150 \mathrm{~mL}$, larutan $\mathrm{HCl}$, larutan $\mathrm{KOH}$, alkohol $70 \%$ dan alkohol 96\%, kertas label, wrapping plastic, aluminium foil, kertas saring. Adapun peralatan yang digunakan : Laminar Air Flow (LAF), autoklaf, timbangan analitik, mikropipet, kamera digital merk Canon Ixus 145 (China), botol kultur, batang pengaduk, pinset, cawan petri.

Tahapan yang dilakukan pada penelitian ini antara lain :

1) Tahap persiapan; semua alat dan bahan yang akan digunakan selama penelitian dibersihkan dengan cara dicuci bersih pada air mengalir dan dikeringkan.

2) Tahap Pembuatan medium MS yang ditambahkan POC jenis nasa: Komposisi medium MS ditunjukkan pada (Tabel 1). Pembuatan medium dilakukan dengan melarutkan unsur hara makro, unsur hara mikro, vitamin, agar, gula, air kelapa $150 \mathrm{~mL}$ yang telah ditimbang dengan timbangan analitik, kemudian dihomogenkan selanjutnya dipanaskan dan dituangkan ke botol kultur yang telah disiapkan dan ditutup rapat dengan wrapping plastics.

3) Tahap sterilisasi dilakukan dengan mensterilkan peralatan dengan menggunakan autoclave pada suhu $121^{\circ} \mathrm{C}$ dan tekanan $15 \mathrm{psi}$ (pound per square inci) selama 15 menit. 
Tabel 1. Komposisi Medium Pupuk Organik Cair (tertera pada label) yang digunakan sebagai media pertumbuhan Cendana (Santalum album L.)

\begin{tabular}{llc}
\hline \hline No & \multicolumn{1}{c}{ Unsur (elemen) } & Nasa (\%) \\
\hline 1 & $\mathrm{~N}$ & 0,06 \\
2 & Senyawa N & - \\
3 & $\mathrm{P} 2 \mathrm{O} 5$ & 0,01 \\
4 & $\mathrm{~K} 2 \mathrm{O}$ & 0,11 \\
5 & $\mathrm{~S}$ & 0,10 \\
6 & $\mathrm{Si}$ & 0,01 \\
7 & $\mathrm{Cl}$ & 0,26 \\
8 & $\mathrm{SO} 4$ & 0,31 \\
9 & $\mathrm{NaCl}$ & 0,98 \\
10 & $\mathrm{Ca}$ & $61,04 \mathrm{ppm}$ \\
11 & $\mathrm{~B}$ & $42,49 \mathrm{ppm}$ \\
12 & $\mathrm{Zn}$ & $37,08 \mathrm{ppm}$ \\
13 & $\mathrm{Mg}$ & $14,54 \mathrm{ppm}$ \\
14 & $\mathrm{Cu}$ & $6,45 \mathrm{ppm}$ \\
15 & $\mathrm{Al}$ & $6,38 \mathrm{ppm}$ \\
16 & $\mathrm{Na}$ & $0,13 \mathrm{ppm}$ \\
17 & $\mathrm{Fe}$ & $0,43 \mathrm{ppm}$ \\
18 & $\mathrm{Mn}$ & $2,30 \mathrm{ppm}$ \\
19 & $\mathrm{Co}$ & $2,13 \mathrm{ppm}$ \\
20 & $\mathrm{Se}$ & $0,1 \mathrm{ppm}$ \\
21 & $\mathrm{Cr}$ & $<, 05 \mathrm{ppm}$ \\
22 & $\mathrm{Mo}$ & $<, 2 \mathrm{ppm}$ \\
23 & $\mathrm{C}$ organik & 4,53 \\
24 & $\mathrm{Bahan}$ Organik & 0,01 \\
\hline \hline
\end{tabular}

4) Tahap sterilisasi biji Cendana dan penanaman dilakukan dengan mencuci biji Cendana terlebih dahulu pada air mengalir untuk membersihkan kotoran yang menempel pada kulit biji, kemudian biji direndam dengan air bersih selama kurang lebih 24 jam. Setelah proses perendaman, kulit biji dikupas dan dicuci bersih, dilanjutkan sterilisasi menggunakan fungisida dithane selama 5-10 menit, kemudian sterilisasi dilanjutkan dengan menggunakan sodium hipoklorit dan direndam dengan alkohol $70 \%$. Setelah itu dibilas dengan akuades steril, biji cendana yang telah disteril, dilektakkan pada cawan petri yang diberi kertas saring steril untuk menyerap sisasisa air pada biji. Tahapan selanjutnya proses penanaman biji cendana pada medium MS dengan penambahan POC masing-masing sebanyak $0 \mathrm{~mL}$ (kontrol), $1 \mathrm{~mL}, 2 \mathrm{~mL}, 3 \mathrm{~mL}$, dan $4 \mathrm{~mL}$ dengan masing-masing sebanyak 3 kali ulangan.

5) Tahap Pengamatan; variabel yang diamati, yaitu: jumlah biji cendana yang berkecambah, persentase perkecambahan, dan tinggi kecambah dengan lama waktu pengamatan 3 bulan.

\section{Hasil dan Pembahasan}

Sampel Biji Cendana ditandai dengan kulit biji berwarna hitam dan bagian dalam berwarna putih dan berbentuk bulat, dengan diameter biji Cendana 0,5-0,8 cm. Biji ini termasuk dalam jenis biji ortodoks. Biji tersebut kemudian disimpan dalam botol kedap udara sehingga dapat mempertahankan kadar air pada biji selama masa penyimpanan pada ruangan dengan suhu kurang lebih $4^{\circ} \mathrm{C}$ dan kelembapan $40-50 \%$ untuk mempertahankan kualitas benih sampai benih ditanam.

Proses perkecambahan biji Cendana dilakukan secara in vitro dengan menanam biji Cendana pada medium MS yang telah diberi POC jenis nasa dengan konsentrasi $0 \mathrm{~mL}$ (kontrol), $1 \mathrm{~mL}, 2 \mathrm{~mL}, 3 \mathrm{~mL}$, dan $4 \mathrm{~mL}$. Perkecambahan merupakan tahap awal perkembangan suatu tumbuhan, khususnya tumbuhan berbiji. Dalam tahap ini, embrio di dalam biji yang semula berada pada kondisi dorman mengalami sejumlah perubahan fisiologis yang menyebabkan embrio berkembang menjadi tumbuhan muda yang dikenal sebagai kecambah. Menurut Solle, dkk (2016), Perkecambahan adalah proses 
pertumbuhan embrio dan komponen biji yang mempunyai kemampuan untuk tumbuh secara normal menjadi tanaman baru atau dengan kata lain perkecambahan adalah awal dari pertumbuhan tanaman yang berasal dari biji yang berisi embrio yang sebelumnya mengalami dormansi. Faktor yang mempengaruhi perkecambahan antara lain faktor lingkungan, faktor perlakuan pasca panen, dan faktor fisiologis biji cendana. Dormansi biji juga menjadi salah satu penyebab biji tidak berkecambah meskipun tumbuh pada tempat yang sesuai. Eksplan yang berasal dari biji yang dikecambahkan secara in vitro mempunyai keuntungan karena kondisi eksplan yang dihasilkan steril. Perkecambahan biji Cendana yang dilakukan secara in-vitro disajikan pada Tabel 2.

Tabel 2. Perkecambahan biji tanaman cendana (Santalum album L.) pada medium MS

\begin{tabular}{cccccc}
\hline \hline Medium & $\begin{array}{c}\text { Konsentrasi } \\
\text { POC Nasa } \\
(\mathbf{m L})\end{array}$ & $\begin{array}{c}\text { Jumlah biji } \\
\text { yang ditanam }\end{array}$ & $\begin{array}{c}\text { Banyaknya } \\
\text { kecambah } \\
\text { yang tumbuh }\end{array}$ & $\begin{array}{c}\text { Persentase } \\
\text { perkecambahan } \\
\text { biji (\%) }\end{array}$ & $\begin{array}{c}\text { Tinggi } \\
\text { kecambah } \\
(\mathbf{c m})\end{array}$ \\
\hline \hline \multirow{4}{*}{ MS } & 0 & 9 & 2 & 22,2 & 3,5 \\
& 1 & 9 & 2 & 22,2 & 8,9 \\
& 2 & 9 & 6 & 66,7 & 0 \\
\hline \hline \\
\hline \hline
\end{tabular}

Perkecambahan Cendana pada medium MS menunjukkan pertumbuhan yang cukup baik dengan nilai rata-rata persentase perkecambahan sebesar 22\%. Berdasarkan hasil yang diperoleh menunjukkan bahwa viabilitas benih cendana masih tergolong rendah. Hal ini di karenakan mutu biji cendana yang digunakan sebagai sumber eksplan merupakan biji cendana yang telah dipanen pada bulan September 2018.

Mutu fisiologis biji yang rendah berkaitan dengan aktivitas enzim, reaksi biokimia serta respirasi biji cendana. Mutu biji akan menurun apabila biji disimpan pada keadaan yang tidak menguntungkan. Syarat umum dalam pengembangan biji adalah kemampuan daya kecambah minimal $80 \%$. Mutu biji juga dipengaruhi oleh lama penyimpanan, biji yang sudah lama disimpan akan mengalami penurunan viabilitas. menurunnya vigor dan kematian biji dapat dilihat dari dua aspek yaitu: hilangnya viabilitas biji dan kematian benih. Proses kematian biji terjadi secara perlahan-lahan, sehingga sulit untuk menentukan waktu berakhirnya kehidupan biji tersebut. Berdasarkan data pengamatan yang dilakuakn terlihat bahwa tinggi kecambah bervariasi, POC jenis nasa dengan konsentrasi $1 \mathrm{~mL}$ memberikan respon tinggi $8,9 \mathrm{~cm}$. Diduga pada konsentrasi ini sel merespon pertambahan panjang sel dengan meningkatkan jumlah sel kecambah Cendana.

Perkecambahan juga dipengaruhi oleh faktor luar dan faktor dalam, faktor luar seperti air, suhu, $\mathrm{O}_{2}$, cahaya dan medium. Sedangkan faktor dalam seperti tingkat kematangan benih, ukuran benih, dormansi dan zat penghambat (Ajar, 2015). Adapun yang menjadi dasar mekanisme biji, adanya kemampuan dormansi, yang terbagi menjadi dormansi fisiologis dan dormansi fisik. Dormansi fisiologis merupakan dormansi yang disebabkan oleh terjadinya hambatan dalam proses fisiologi seperti embrio rudimenter, keseimbangan hormonal dalam benih, dan metabolik blok pada kotiledon benih. Dormansi fisik merupakan dormansi yang disebabkan oleh adanya pembatas struktural terhadap perkecambahan benih, seperti kulit benih yang keras dan kedap sehingga menjadi penghalang mekanis terhadap masuknya air atau gas ke dalam benih. 


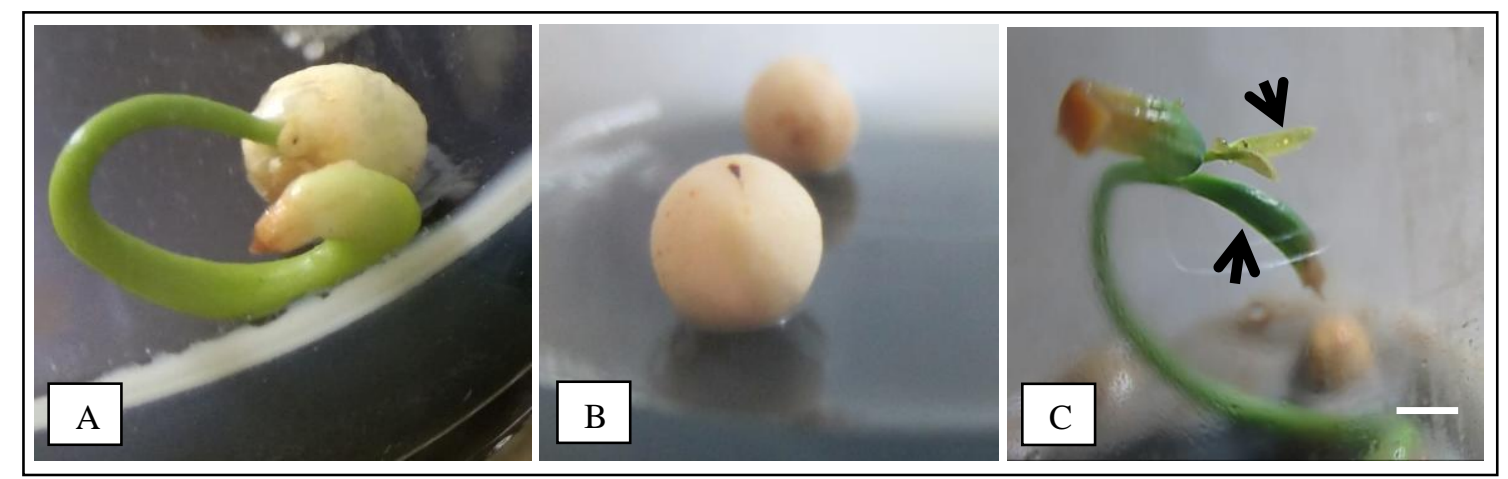

Gambar 1. Pertumbuhan cendana (Santalum album L.) secara invitro dengan adanya pembentukan daun Cendana. Skala bar $1 \mathrm{~mm}$.

Pada biji Cendana terdapat endosperm yang mengandung massa pati yang di keliling oleh suatu lapisan yaitu aleuron. Sedangkan embrio itu sendiri berpotensi untuk dapat berkembang menjadi tanaman dewasa. Pertumbuhan embrio selama perkecambahan, bergantung pada persiapan bahan makanan yang berada dalam endosperm. Untuk keperluan kelangsungan hidup embrio, maka terjadilah penguraian secara enzimatik yaitu terjadi perubahan pati menjadi gula yang selanjutnya di translokasikan ke embrio sebagai sumber energi untuk pertumbuhannya.

Gambar 2 menunjukkan beberapa bagian dari kecambah biji cendana. Hipokotil merupakan bagian dari kecambah yang diyakini memiliki kandungan auksin endogen yang cukup tinggi karena letaknya di bawah tajuk dan menjadi tempat lintasan pengangkutan auksin. Daun muda dan daun sejati yang muncul pada 8 minggu pengamatan sebanyak 2 helai daun dengan kenampakan daun berwarna hijau, kemunculan daun disebabkan karena peran POC untuk merangsang pembentukan daun dari pada pemanjangan batang dan pembentukan akar. Menurut Mebeng, 2016 POC Nasa membantu menyediakan unsur hara yang cukup sehingga tanaman mampu melaksanakan aktivitas dengan baik yang hasilnya dimanfaatkan untuk perkembangan sel tumbuhan.

Bagian bawah hipokotil yang tumbuh akan memunculkan akar, kemunculan akar sebagai akibat adanya respon terhadap penambahan POC, yang berfungsi untuk merangsang perkecambahan bekerja sama dengan zat pengatur tumbuh endogen pada biji Cendana berupa Giberelin dan auksin. Pemberian $\mathrm{GA}_{3}$ dapat meningkatkan perkecambahan benih meskipun dalam kondisi lingkungan yang kurang optimal, sehingga diperlukan hormon $\mathrm{GA}_{3}$ sebagai pendorong perkecambahan tumbuhan setelah proses imbibisi dan menyediakan cadangan makanan untuk pertumbuhan embrio dalam perkecambahan benih. $\mathrm{GA}_{3}$ dapat berfungsi untuk menghilangkan zat penghambat perkecambahan, mematahkan dormansi dan mengaktifkan enzim yang berperan dalam meningkatkan aktifitas metabolik (Lestari, 2009). Jika $\mathrm{GA}_{3}$ tidak ada atau kurang aktif maka $\alpha$-amilase tidak akan terbentuk yang akan menyebabkan terhalangnya proses perombakan pati, sehingga dapat mengakibatkan tidak terjadinya perkecambahan.

Menurut Salisbury dan Ross (1995), auksin alami disintesis pada bagian meristem tajuk serta daun dan buah yang sedang tumbuh, selanjutnya akan diangkut dari sel ke sel dengan arah basipetal (dari pucuk ke akar). Dimana pada bagian tersebut merupakan daerah yang kaya akan auksin. Auksin di dalam tubuh tumbuhan mempunyai pengaruh yang sangat kompleks dan dapat mengendalikan pertumbuhan. Pupuk organik adalah pupuk yang sebagian besar atau seluruhnya terdiri atas bahan organik yang berasal dari sisa tanaman atau hewan yang telah mengalami rekayasa berbentuk padat atau cair yang digunakan untuk memasok bahan organik, memperbaiki sifat fisik, kimia dan biologi tanah (Nur, 2016) . Pengomposan atau pembuatan pupuk organik merupakan suatu metode untuk mengkonversikan bahan-bahan organik menjadi bahan yang lebih sederhana dengan menggunakan aktivitas mikrobia (Krismawati $d k k$, 2016). 


\section{Simpulan}

Pemberian POC pada kultur biji Cendana berpengaruh terhadap perkecambahan biji meskipun kemampuan perkecambahannya masih tergolong rendah sehingga perlu dilakukan penelitian dengan konsentrasi POC yang lebih bervariasi. Penambahan $2 \mathrm{~mL}$ POC pada medium kultur memberikan pengaruh terbaik dalam memacu perkecambahan biji Cendana.

\section{Ucapan Terima Kasih}

Terima kasih kepada DRPM Kemenristekdikti yang telah memberikan dana untuk pelaksanaan penelitian ini.

\section{Daftar Pustaka}

Anonymous.,2011., Masterplan Pengembang dan Pelestarian Cendana Provinsi Nusa Tenggara Timur tahun 2010-2030. Balai Penelitian Kehutanan. Kupang.

Ajar, S. 2015. Pengaruh Konsentrasi Air Kelapa dan Lama Perendaman Terhadap Perkecambahan Benih Padi (Oryza sativa L) Kadaluarsa. Pertanian. Universitas Teuku Umar. Meulaboh Aceh Barat.
Indrianto, A., 2003. Kultur Jaringan Tumbuhan. Fakultas Biologi. Universitas Gadjah Mada. Yogyakarta.

Krismawati, A dan Hardini D., 2014. Kajian beberapa dekomposer terhadap kecepatan dekomposisi sampah Rumah tangga. Vol. 14. No 2: 79-89. Buana Sains. Malang.

Lina, F.R., Ratnasari, E., Wahyono, R. 2013. Pengaruh 6benzylamino purine (BAP) dan 6-furfuryl amino purine (Kinetin) pada media MS terhadap pertumbuhan eksplan ujung apikal tanaman jati secara in vitro. Lentera Bio. ISSN 2252-3979.

Lestari, S. 2009. Pengaruh pemberian sitokinin dan asam Giberelin $\left(\mathrm{GA}_{3}\right)$ terhadap perkecambahan biji dan pertumbuhan tanaman pule pandak (Rauvolfia verticillata L). Universitas Sebelas Maret. Surakarta.

Mebeng, E.S., Astuti, P., 2016. Pengaruh pemberian Pupuk Organik Cair Nasa dan Pupuk kandang ayam terhadap pertumbuhan dan produksi tanaman selada (Lactuca sativa L.). Jurnal Agrifor, XV(1). ISSN : 1412-6885. pp 37-42.

Nur, T et al., 2016. Pembuatan pupuk organik cair dari sampah organik rumah tangga dengan penambahan bioaktivastor EM4. Jurnal Konversi, Vol. 5 No. 2.

Ndolu, H., 2018. Pengaruh perlakuan pematahan dormansi terhadap viabilitas benih Cendana (Santalum album L.). Skripsi. Universitas Kristen Artha Wacana. Kupang.

Salisbury, F.B., Ross C.W., 1995. Fisiologi Tumbuhan Jilid 3. Bandung. ITB

Solle, H.R.L dan Semiarti, E., 2016. Micropropagation of Sandalwood (Santalum album L.) endemic plant from East Nusa Tenggara, Indonesia. AIP Conference Proceedings. AIP Publishing. 